Language and Cognition 0 (2017), 1-13. doi:10.1017/langcog.2017.6

(C) UK Cognitive Linguistics Association, 2017

\title{
Morphology in Spanish-speaking children with Williams syndrome*
}

ANTONIO BENÍTEZ-BURRACO

Departamento de Filología Española y sus Didácticas, Facultad de Humanidades Universidad de Huelva, Spain

ELENA GARAYZÁBAL

Departamento de Lingüistica General, Facultad de Filosofía y Letras, Universidad Autónoma de Madrid, Spain

AND

\section{A B S T R ACT}

Aims. Morphological skills in Williams syndrome (WS) are a controversial issue, particularly cross-linguistically. Methods. We assessed pluralization patterns of nouns, inflection of verbs in the past, and gender assignment, inflection, and agreement within the noun phrase in a sample of Spanishspeaking children with WS compared to typically developing (TD) children matched on mental age (VA-TD) and on chronological age (CA-TD) age. Results. Children with WS attribute grammatical gender correctly in a production task, but they have problems with inferring the referent's sex from the gender of the noun in a comprehension task. Additionally, they correctly pluralize nouns and properly inflect regular verbs, but they have problems with irregular verbs. Our findings suggest that they have mastered the productive rules, but they perform like younger children regarding irregular items.

[*] We wish thank the parents and children who made this study possible. Preparation of this work was supported in part by funds from the Spanish Ministry of Economy and Competitiveness (grant numbers FFI2014-61888-EXP and FFI-2013-43823-P to ABB). Address for correspondence: Antonio Benítez Burraco, Departamento de Filología Española y sus didácticas, Facultad de Humanidades, Campus de 'El Carmen', Universidad de Huelva, Avda. de las Fuerzas Armadas s/n. 21071-Huelva, Spain. tel: 0034959219 113; e-mail: antonio.benitez@dfesp.uhu.es 
KEYWORDS: William syndrome, Spanish, morphology, plural nouns, past verbs, gender agreement.

\section{$\mathrm{AQ} 2$ 1. Introduction}

Williams-Beuren syndrome (hereafter, WS) is a developmental disorder caused by a microdeletion in one copy of the chromosome 7 affecting two dozen genes (Korenberg et al., 2008). The hemizygosis of these genes contribute to the physical, cognitive, and socio-affective impairments characteristic of the disorder, although a one-to-one correlation between genes and dysfunctions has been difficult to prove (Bellugi, Korenberg, \& Klima, 2001; Tassabehji, 2003).

First studies of the disorder reported that language is spared in WS, whereas other abilities (visuospatial cognition and social skills) are impaired. Recent, fine-grained analyses have concluded that problems with structural components of language (i.e., morphology, syntax, etc.) exist that remain to be explained. Morphological abilities of people with WS are a controversial issue. A main concern has been whether the observed deficits support a distinction between a computationally based (regular) inflectional mechanism and a lexically based (irregular) inflectional device, as proposed by the wordand-rule theory of inflection (Pinker \& Prince, 1994). According to several authors (e.g., Bromberg, Ullman, Marcus, Kelly, \& Levine, 1995; Clahsen \& Almazan, 1998; Krause \& Penke, 2002; Clahsen, Ring, \& Temple, 2004) only the latter is impaired. Others (e.g., Thomas et al., 2001) have argued that people with WS do not exhibit any unusual pattern of dissociation between regular and irregular forms, but only a developmental delay in the acquisition of this component of grammar.

This question remains inconclusive in spite of a growing corpus of crosslinguistic data. Children with WS acquiring Hebrew (a Semitic language that inflects the verb by adding vowels to consonantal roots) master a basic control of root structure, although they exhibit a poorer performance and/or a delay with regards to specific morpho(phono)logical processes (Levy \& Bechar, 2003; Levy \& Hermon, 2003). Children with WS acquiring French (an inflectional language) or Hungarian (an agglutinative language) are sometimes delayed compared to typically developing (TD) children matched for mental age, but qualitative differences are not observed between groups (KarmiloffSmith, Grant, Berthoud, Davies, Howlin, \& Udwin, 1997; Lukács, Racsmány, \& Pléh, 2001; Pléh, Lukács, \& Racsmány, 2003).

The aim of this work is twofold. First, we aim to contribute to the ongoing discussion on the nature of morphological (dis)abilities in people with WS. Additionally, we want to contribute to the ongoing discussion about crosslinguistic differences between people with WS. Most research on this topic has been conducted on English-speaking populations. Here, we analyze a 
Spanish-speaking group with WS. In contrast to English, Spanish is a highly inflected language. Nouns are inflected for number and gender. Singular is the unmarked number. Plurals are marked with $-s$ or $-e s$, or remain invariable, depending on complex morphophonological rules. All Spanish nouns are assigned a grammatical gender (masculine or feminine), even if it refers to a sexless entity. Gender is occasionally marked in the noun (adding -o to masculine and - $a$ to feminine), but frequently is only overtly marked in the determiner. Also in contrast to English, Spanish verbs are highly inflected. Inflectional suffixes convey different kind of grammatical information (person, number, mood, tense, aspect). Moreover, there are regular and irregular verbal paradigms involving different allomorphs and different kinds of morphophonological alternations.

\section{Method}

\subsection{PARTICIPANTS}

Three groups of participants took part in this study. The experimental group comprised thirteen children with WS (six boys and seven girls, mean chronological age $10 ; 7$, range 7;3-15;6). Diagnosis was confirmed by fluorescence in situ hybridization (FISH) to the elastin gene deletion in chromosome 7 , a robust marker for WS. Thirteen TD children (six boys and seven girls, mean chronological age 6;4, range 5;4-7;4), matched to the WS group on verbal mental age, composed the first control group (hereafter, VA-TD). Eight TD children (four boys and four girls, mean chronological age $10 ; 4$, range $8 ; 0-12 ; 5)$ formed the second control group that was matched on chronological age (hereafter, CA-TD) to the WS group. All participants were monolingual native speakers of Castilian Spanish. The participants had no hearing deficits. For all groups, their parents provided written consent for their participation in the study.

The WS and the VA-TD groups were matched according to the short form of the Wechsler Intelligence Scale for Children-Fourth Edition (WISC-IV) and also to a lexical decision task (Table 1). This version of the WISC-IV provides high levels of reliability and validity when applied to research (see Demsky, Gass, Edwards, \& Golden, 1988, for Spanish-speaking populations). The short version of the WISC-IV test comprises four subtests: Coding, Picture Completion, Similarities, and Digit Span, each of which represents a main index of the WISC-IV: the Processing Speed Index (PSI), the Perceptual Reasoning Index (PRI), the Verbal Comprehension Index (VCI), and the Working Memory Index (WMI), respectively. Significant differences between the WS group and the VA-TD group were observed only in the Digit symbol Coding and Picture Completion subtests (Table 1). With regards to the lexical decision task, a total of sixteen words and sixteen pseudo-words 
BENÍTEZ-BURRACO ET AL.

TA B LE 1. Cognitive and verbal assessment: mean (and SD) in each subtest of the three experimental groups

\begin{tabular}{|c|c|c|c|c|c|}
\hline WISC-IV subtest & WS & VA-TD & $\begin{array}{c}\text { Sign. } \\
\text { (WS/VA-TD) }\end{array}$ & CA-TD & $\begin{array}{c}\text { Sign. } \\
(\mathrm{WS} / \mathrm{CA}-\mathrm{TD})\end{array}$ \\
\hline $\begin{array}{l}\text { Digit Symbol coding } \\
\text { (PSI) }\end{array}$ & $18.46(12.02)$ & $30.23(10.06)$ & .022 & $46.37(9.47)$ & .000 \\
\hline $\begin{array}{l}\text { Picture completion } \\
\text { (PRI) }\end{array}$ & $9.46(5.22)$ & $14.38(4.03)$ & .022 & $27.00(5.50)$ & .000 \\
\hline $\begin{array}{l}\text { Similarities } \\
\text { (VCI) }\end{array}$ & $9.15(2.58)$ & $11.85(4.06)$ & .082 & $26.13(6.87)$ & .000 \\
\hline $\begin{array}{l}\text { Digit span } \\
\text { (WMI) }\end{array}$ & $8.54(2.54)$ & $10.23(2.98)$ & .116 & $15.75(1.75)$ & .000 \\
\hline Lexical decision task & $26.15(3.74)$ & $29.00(2.34)$ & .087 & $29.38(1.18)$ & .105 \\
\hline
\end{tabular}

(primitive and morphologically derived) were randomly mixed and presented orally; the participants had to say whether it was a real word or not. The frequency band employed was low, between three and nineteen occurrences per million (with a mean value of 9.8). No significant differences were found between groups, nor any ceiling effect (see Section 2.2.1 below). The CA-TD scored significantly higher than the WS group in the four subtests of the WISC-IV. No statistical differences were found regarding the lexical decision task (Table 1).

\subsection{TAS K S}

We designed four tasks to assess how nouns and verbs are inflected by Spanish children with WS. In order to be able to establish confident cross-linguistic comparisons we built on tasks previously tested in English and French populations with WS.

\subsubsection{Task 1: noun inflection}

This task was based in the WUG test (Berko, 1958). Thirty-two items accounting for all the pluralization patterns in Spanish evaluated the participant's ability to pluralize nouns: (the number of items comprising each subgroup roughly equates to its frequency in the Spanish lexicon):

- fourteen nouns and pseudo-nouns ending in a tonic -á/-é/-ó, or in an unstressed vowel (these nouns add -s to the singular). This is one of the two main pluralization patterns in Spanish (e.g., foca/focas 'seal/seals'); - eight nouns and pseudo-nouns ending in a consonant other than $-s$ (these nouns add -es to the singular). This is the second main pluralization pattern in Spanish (e.g., calamar/calamares 'squid/squids'); 
- three polysyllabic nouns and pseudo-nouns ending in $-s$ and in a tonic syllable, and that are not compounds (these nouns add -es to the singular) (e.g., compás/compases 'compass/compasses');

- three polysyllabic nouns ending in $-s$ and in a tonic syllable, and that are compounds (these nouns remain invariable in plural) (e.g., saltamontes/saltamontes 'grasshopper/grasshoppers');

- two nouns and pseudo-nouns ending in a tonic -i/-ú, (these nouns add either $-s$ or -es to the singular) (e.g., jabali/jabalies, jabalís 'wild boar / wild boars');

- two polysyllabic pseudo-nouns ending in $-s$ and in atonic syllable (these nouns remain invariable in the plural) (e.g., lunes/lunes 'Monday/ Mondays').

The children were shown pictures displaying two or three exemplars of each item. Afterwards, they were verbally stimulated to generate the plural forms of the substantives: "Mira, un elefante. Y ahora, ¿̇cuántos hay?" 'Look, an elephant. How many are there now?'; "Mira, un resijel [pseudo noun]. Y ahora, ¿cuántos hay?" 'Look, a resijel. How many are there now?'. Expected answer: "Hay tres elefantes" 'There are three elephants'; "Hay tres resijeles" 'There are three resijeles'.

\subsubsection{Task 2: gender attribution, gender inflection, and gender agreement (I)}

This is a production task. We relied on the tasks designed by KarmiloffSmith et al. (1997). In Spanish masculine nouns sometimes add -o to the root (pat-o 'duck $\mathrm{MASC}_{\mathrm{M}}$ '), while feminine nouns add - $a$ (pat-a ' $\mathrm{duck}_{\mathrm{FEM}}$ '). Nevertheless, in many cases grammatical gender is expressed in the determiner only (see examples below). For each noun we used a drawing displaying three exemplars painted in different colours and with specific gender attributes (a hat and a tie for males and a ribbon and a collar for females). Nouns were introduced with the cardinal numeral tres 'three': "Mira, tres patos" 'Look, three ducks' (yellow, red, and white). Afterwards, the child was shown only two of the specimens (for example, the yellow and the red ones) and then asked: "¿Cuál falta ahora?" 'And here, which one is missing?'. In order to answer this question correctly, appropriate gender agreement between the article, the noun, and the adjective has to be performed: $E l_{\text {MASC }}$ pato $_{\text {MASC }}$ blanco $_{\text {MASC }}$ 'the white duck'. Our task consisted of thirty-two items and six subgroups (the number of items comprising each subgroup roughly equates to its frequency in the Spanish lexicon):

- nine nouns and pseudo-nouns not ending in either - $o$ or in - $a$ applied to masculine drawings (e.g., $p e z$ ' fish $_{\text {MASC }}$ '); 
- eight nouns and pseudo-nouns not ending in either -o or in - $a$ applied to feminine drawings (e.g., serpiente 'snake ${ }_{\mathrm{FEM}}$ ');

- six nouns and pseudo-nouns ending in $-a$ applied to feminine drawings (e.g., tigresa 'tiger ${ }_{\mathrm{FEM}}$ ');

- five nouns and pseudo-nouns ending in -o applied to masculine drawings (e.g., oso 'bear ${ }_{\text {Masc }}$ ');

- two pseudo-nouns ending in -o applied to feminine drawings (e.g., coto 'cotoFEM');

- two pseudo-nouns ending in - $a$ applied to masculine drawings (e.g., resija 'resija $\mathrm{MASC}_{\mathrm{MA}}$ ').

\subsubsection{Task 3: gender attribution, gender inflection, and gender agreement (II)}

This is a comprehension task. It was aimed at assessing how gender is attributed to nouns, whether relying on the noun ending or on the inflectional suffix in the determiner. Three different types of nouns and pseudo-nouns were included: ending in $-a$, ending in $-o$, and ending in other than $-a /-o$. They were introduced by either the masculine article $e l$ 'the Masc' ' or the feminine article $l a$ 'the FEM $_{\mathrm{FE}}$. In this task we made use of the same items that we employed for the Task 2 (Section 2.2.2). Two pictures were shown to the children: one depicting an exemplar with male attributes (a hat and a tie) and the other showing the same creature with female attributes (a ribbon and a collar).

\subsubsection{Task 4: verb inflection}

This is a production task. We prepared a list of thirty-two verbs and pseudoverbs, existing and non-existing, regular and irregular. We asked the children to generate the simple (inflected) past forms, according to the methodology described by Clahsen and Almazan (1998) and Thomas et al. (2001). Our sample consisted of ten subgroups of verbs (real verbs and real verbal roots (for pseudo-words) were selected according to their length and frequency, to achieve homogeneous samples):

- four irregular pseudo-verbs derived from existing verbal bases by adding existing prefixes (e.g., pretraer = pre 'previous' + traer 'take');

- four irregular non-existing verbs derived from existing verbal bases by adding non-existing prefixes (e.g., pilpedir $=$ pil + pedir 'ask');

- four simple (i.e., non-derived) irregular verbs (e.g., dormir 'to sleep');

- four derived irregular verbs (e.g., predecir 'to foretell');

- two regular non-existing verbs derived from existing nominal bases by suffixation (e.g., croquetear, from croqueta 'croquette'); 
- two regular non-existing verbs derived from non-existing nominal bases by suffixation (e.g., pilear);

- two regular non-existing verbs derived from existing verbal bases by adding existing prefixes (e.g., presubir = pre + subir 'go up');

- two regular non-existing verbs derived from existing verbal bases by adding non-existing prefixes (e.g., pilsaltar $=$ pil + saltar 'jump');

- four simple (i.e., non-derived) regular verbs (e.g., hablar 'to talk');

- four derived regular verbs (e.g., preparar 'to prepare').

Verbs were presented in their infinitive form. A linguistic context was provided to trigger the simple past form: e.g., "Yuan duerme con su abuela cada dia. Ayer también ... [durmió con su abuela]" 'John sleeps with his grandma every day. Yesterday he also ... [slept with his grandma]'

\subsection{PRO CED URE}

All participants were individually tested over two days. On the first day, their cognitive profile was assessed according to the WISC-IV. We applied the linguistic tests in two separate sessions during the second day, because they were highly demanding for the WS participants. We also avoided distractions that might affect their performance because of their limited sustained attention. Target sentences were read aloud by the experimenter, who used a neutral prosody. This protocol was kept the same across tasks and across experimental groups. The tasks were always introduced by an example. To check that the child had correctly understood what she was expected to do, the experimenter first read the question in the example and asked the child to provide an answer. When the child did not understand the procedure, the experimenter read the question for a second time and provided him with the correct answer. Next, the same question was read again to the child who was encouraged to provide an answer by himself. After this, the target sentences were read (only once) and the answers were written down. Depending on the task, participants had to point at the drawing that matched the given input or give an oral answer. Correct answers were given a score of 1 , while incorrect answers were given a score of 0 (oral answers were also analyzed qualitatively).

\section{Results}

\subsection{GENERAL OVERVIEW}

The performance of the WS and the control groups was compared using non-parametric statistics (Mann-Whitney $U$ test). Table 2 shows the mean scores, the standard deviations, and the statistical significance of the differences between groups. 
BENÍTEZ-BURRACO ET AL.

TABLE 2. Mean (and SD) of correct responses in Tasks 1, 2, 3, 4

\begin{tabular}{lcccccc}
\hline Task & $\mathrm{N}$ & WS & VA-TD & $\begin{array}{c}\text { Sign. } \\
\text { (WS/VA-TD) }\end{array}$ & CA-TD & $\begin{array}{c}\text { Sign. } \\
\text { (WS/CA-TD) }\end{array}$ \\
\hline $\begin{array}{l}\text { 1. Noun inflection } \\
\begin{array}{l}\text { 2. Gender attribution, } \\
\text { gender inflection, }\end{array}\end{array}$ & 32 & $26.23(2.83)$ & $27.54(1.98)$ & .233 & $28.80(1.09)$ & .067 \\
$\begin{array}{l}\text { and gender } \\
\text { agreement (I) }\end{array}$ & $24.85(1.62)$ & .161 & $25.80(0.83)$ & .073 \\
$\begin{array}{l}\text { 3. Gender attribution, } \\
\text { gender inflection, }\end{array}$ & 32 & $27.31(2.25)$ & $31.62(0.87)$ & .000 & $31.40(0.89)$ & .002 \\
$\begin{array}{l}\text { and gender } \\
\text { agreement (II) }\end{array}$ & & & & & & \\
\begin{tabular}{l} 
4. Verb inflection \\
\hline
\end{tabular} & 32 & $16.54(5.21)$ & $17.69(2.14)$ & .639 & $20.60(3.05)$ & .019 \\
\hline
\end{tabular}

The WS group scored significantly lower than the CA-TD and the VA-groups in the task that evaluated the comprehension of gender attribution, gender inflection, and gender agreement (Task 3, Section 2.2.3). Close to significant results were observed in the task that assessed verbal inflection (Task 4, Section 2.2.4), but only compared the CA-TD group (Table 2). The variability of the scores obtained by the WS group was slightly greater than that of the VA-TD group. Because of the several types of items we have considered, we provide below a qualitative analysis of the results. Whenever items can be grouped in larger subcategories (e.g., problems with regular vs. irregular verbs in Task 4), we also give the significance of the differences according to the Mann-Whitney $U$ test.

\subsection{NOUN INFLECTION (TASK 1$)$}

In this task, significant differences between the WS and the VA-TD groups were observed regarding nouns ending in a tonic $-\dot{a},-e ́ /-o ́$, or in an unstressed vowel (Table 3 ). These nouns get a $-s$ allomorph in the plural form. Pseudo-nouns or infrequent nouns were problematic for children with WS. Usually they relied on the singular form (e.g., ictó/*ictó; orangután 'orangutan'/*orangután; gibón 'gibbon'/*gibón). Overall, although nonexisting nouns were processed more poorly than the real ones, differences between groups were not significant (Table 3).

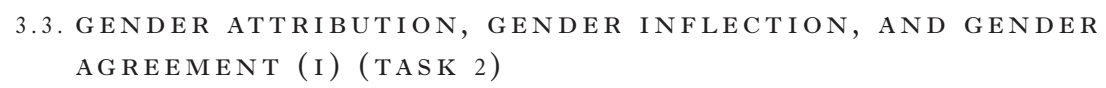

Differences between the WS and the VA-TD groups in this task were not significant (Table 2). Overall, the task seemed problematic for TD children 
MORPHOLOGY IN WILLIAMS SYNDROME

TA B LE 3. Mean (and SD) of correct responses in noun inflection (Task 1)

\begin{tabular}{|c|c|c|c|c|c|c|}
\hline Task & $\mathrm{N}$ & WS & VMA-TD & $\begin{array}{c}\text { Sign. } \\
\text { (WS/VA-TD) }\end{array}$ & CA-TD & $\begin{array}{c}\text { Sign. } \\
(\mathrm{WS} / \mathrm{CA}-\mathrm{TD})\end{array}$ \\
\hline $\begin{array}{l}\text { Nouns ending in a } \\
\text { tonic }-\dot{a} /-\dot{e} /-\dot{o} \text {, or } \\
\text { in an unstressed } \\
\text { vowel }\end{array}$ & 14 & $13.31(0.63)$ & $14.00(0.0)$ & .001 & $13.88(0.35)$ & .031 \\
\hline $\begin{array}{l}\text { Nouns ending in } \\
\text { consonant but } \\
\text { not in }-s\end{array}$ & 8 & $4.31(2.10)$ & $5.00(1.68)$ & .322 & $6.00(0.76)$ & .027 \\
\hline Pseudo-nouns & 16 & $12.08(1.80)$ & $12.73(1.30)$ & .248 & $13.50(1.31)$ & .055 \\
\hline Real nouns & 16 & $14.15(1.52)$ & $14.77(0.93)$ & .366 & $15.88(0.35)$ & .002 \\
\hline
\end{tabular}

too, who did not score at ceiling. Children with WS significantly underscored when they had to produce noun phrases with three inflectional marks (e.g., $e_{\text {MASC }}$ pato $_{\text {MASC }}$ blanco $_{\text {MASC }}$ ) (Table 4). They also performed significantly worse than the VA-TD group when they had to inflect pseudo-nouns.

\subsection{GENDER ATtRIBUtion, GENDER inflection, AND GENDER AGREEMENT (II) ( TASK 3)}

This task was a challenge for children with WS (Table 2). Differences with the VA-TD and the CA-groups were statistically significant for all conditions, except for real nouns ('Table 5).

\subsection{VERB INFLECTION (TASK 4)}

In this task children with WS scored similarly to their peers matched on VA, but significantly lower than their peers matched on CA on some kind of items (Table 6). Irregular verbs were the most problematic type of verb for them. A qualitative analysis of their answers showed that the most difficult verbs T A B LE 4. Mean (and SD) of correct responses in gender attribution, gender
inflection, and gender agreement I (Task 2)

\begin{tabular}{|c|c|c|c|c|c|c|}
\hline Task & $\mathrm{N}$ & WS & VMA-TD & $\begin{array}{c}\text { Sign. } \\
\text { (WS/VA-TD) }\end{array}$ & CA-TD & $\begin{array}{c}\text { Sign. } \\
\text { (WS/CA-TD) }\end{array}$ \\
\hline $\begin{array}{l}\text { Inflected Det } \\
\text { and N }\end{array}$ & 12 & $10.38(0.51)$ & $11.15(1.28)$ & .009 & $12.00(0.0)$ & .000 \\
\hline $\begin{array}{l}\text { Inflected } \\
\text { Det only }\end{array}$ & 16 & $11.38(1.67)$ & $11.85(0.80)$ & .321 & $12.13(0.35)$ & .166 \\
\hline Pseudo-nouns & 16 & $9.92(1.50)$ & $9.62(0.77)$ & .788 & $10.00(1.69)$ & .970 \\
\hline Real nouns & 16 & $13.85(1.28)$ & $15.23(1.09)$ & .007 & $15.63(1.06)$ & .002 \\
\hline
\end{tabular}


BENÍTEZ-BURRACO ET AL.

TAB LE 5. Mean (and SD) of correct responses in gender attribution, gender inflection, and gender agreement II (Task 3)

\begin{tabular}{|c|c|c|c|c|c|c|}
\hline Task & $\mathrm{N}$ & WS & VMA-TD & $\begin{array}{c}\text { Sign. } \\
\text { (WS/VA-TD) }\end{array}$ & CA-TD & $\begin{array}{c}\text { Sign. } \\
\text { (WS/CA-TD) }\end{array}$ \\
\hline Inflected Det and N & 15 & $12.31(1.32)$ & $14.77(0.83)$ & .000 & $14.75(0.71)$ & .001 \\
\hline Inflected Det only & 17 & $15.00(1.29)$ & $16.85(0.38)$ & .000 & $16.63(0.74)$ & .002 \\
\hline Pseudo-nouns & 16 & $6.54(0.77)$ & $7.77(0.83)$ & .000 & $7.75(071)$ & .003 \\
\hline Real nouns & 16 & $8.85(0.38)$ & $9.00(0.0)$ & .149 & $9.00(0.00)$ & .255 \\
\hline
\end{tabular}

TAB LE 6. Mean (and SD) of correct responses in verb inflection (Task 4)

Task

Sign.

Sign.

Irregular verbs $16 \quad 2.08(1.11) \quad 1.85(1.99) \quad .332$

$\begin{array}{lllll}\text { Regular verbs } & 16 & 14.46(4.43) & 15.85(0.55) & .270\end{array}$

332

270

$12.38(1.85)$

(WS/CA-TD)

for children with WS were derived irregular verbs, either non-real (e.g., condigerir $=$ con ' $w i t h$ ' + digerir 'digest', expected simple past form: condigirió, given answers: *condigerió, *condigeró, ?condigerir) or real (e.g., retener 'retain', expected past form: retuvo, given answers *retenió, * retenó, ?retener).

\section{Discussion}

Our results suggest that the competence achieved by Spanish children with WS parallels that of their peers matched on VA and that of their peers matched on $\mathrm{CA}$ in some areas. The ability that seems to be significantly weaker in them concerns gender assignment, gender inflection, and gender agreement. Next, we discuss the results that we obtained in the areas under scrutiny. At the end of this section, we suggest a possible explanation for what we have observed.

\subsection{NOUN INFLECTION}

Children with WS and VA-TD children perform similarly regarding all pluralization patterns in Spanish, with the exception of nouns ending in a tonic $-a,-e ́ /-o ́$, or in an unstressed vowel. These results are in line Pérez39 Pereira (1989), who found that TD children (aged from three to six years) 40 score significantly lower when the -es allomorph is required. The same 41 has been observed in children with Down Syndrome (Lázaro, Garayzábal, \& 42 Moraleda, 2013). Additionally, we found that children with WS perform 
better with real nouns. Again, this is also in line with Pérez-Pereira (1989), who found that TD children have more problems when they have to pluralize pseudo-words. On the whole, our children with WS behave very much like young TD children. Our results are also in line with what has been observed in children with WS acquiring English, who have mastered the rule for pluralizing nouns, but who still show problems with irregular forms (Bromberg et al., 1995; Clahsen \& Almazan, 1998, for spontaneous speech; Clahsen et al., 2004).

\subsection{Gender Attribution, Gender Morphology, AND GENDER A GREEMENT}

Several lessons can be drawn from our evaluation. First, children with WS drive more efficiently from gender attributes to grammatical gender (as in Task 2) than from grammatical gender to the referent's features (as in Task 3). Second, they perform better with real nouns. In other languages this realworld effect has been pointed out by Clahsen and Almazan (1998) for English, and Boloh, Ibernon, Royer, Escudier, and Danillon (2009) for French. Third, to infer the gender (or the sex) children with WS focus on the noun more than TD children, who focus more on the determiner. Specifically, the low scores obtained with pseudo-nouns not ending in $-o /-a$ which refer to female drawings are in line with Boloh et al. (2009), who found that French children with WS mainly opt for the masculine. According to Karmiloff-Smith et al. (1997), this behaviour suggests that children with WS have learned articlenoun pairs by rote, as TD children also do. Overall, our results support the view that the morphological skills involved are delayed, in line with Boloh's et al . (2009) study of gender attribution in French. Finally, we also observed that the higher the number of variables to be computed, the greater the differences in scores between the WS and the TD groups. Accordingly, in Task 2, children with WS performed significantly worse than their peers matched on VA when gender was also marked in the determiner.

\subsection{VERB INFLECTION}

According to our results, the acquisition of irregular forms is delayed in Spanish children with WS, because they perform quite similarly to their peers matched on VA, but worse than their peers matched on CA. This is plausibly due to the low frequency of irregular forms in the input. Moreover, children with WS consistently over-regularize both irregular verbs (existing or non-existing), as younger TD children also do (at the same time the overregularized forms generated by VA-TD children are canonical). Finally, children with WS correctly compute tense. This suggests that the notion of 
past is mastered early in WS. Our results are in line with Pérez-Pereira (1989), who found that Spanish TD children usually regularize irregular verbs and that irregular pseudo-verbs are assigned to the first conjugation (i.e., drumir [third conjugation] is inflected as drumó [first conjugation], instead of as drumió). We have observed this behaviour too. In contrast, children with WS inflect regular verbs (real and unreal) correctly. This supports the view that they have already mastered the rule needed for generating simple past forms.

On the whole, our results are in line with previous studies in other languages that claim that children with WS have mastered the production of regular past forms, although they still exhibit a poor command of irregular forms, which are mainly over-regularized (Bromberg et al., 1995; Clahsen \& Almazan, 1998; Krause \& Penke, 2002; Clahsen et al., 2004). Moreover, our results support the view that the grammatical knowledge of children with WS is similar to that of younger TD children, as also concluded by many other researchers (e.g., Karmiloff-Smith et al., 1997; Thomas et al., 2001; Lukács et al., 2001; Levy \& Hermon, 2003; Lukács et al., 2004; Lukács, 2005).

To date, very few studies have been conducted on the linguistic abilities of children with WS acquiring Spanish. In this study we have tested several issues regarding noun and verbal morphology, and agreement within the noun phrase. Our results confirm that children with WS perform much as young TD children. Accordingly, they have mastered the morphological rules involved, but they have problems with irregular forms or infrequent items. This may result from a delay in the normal process of restricting the scope of productive rules that are involved in the pluralization of nouns, in gender inflection, and in verbal inflection. At the same time, some processing constraint may account for their lower scores in tasks involving a high number of morphosyntactic cues.

\section{REFEREN CES}

Bellugi, U., Korenberg, J. R., \& Klima, E. S. (2001). Williams syndrome: an exploration of neurocognitive and genetic features. Clinical Neuroscience Research, 1, 217-229.

Berko, J, (1958). The child's learning of English morphology. Word, 14, 150-177.

Boloh, Y., Ibernon, L., Royer, S., Escudier, F., \& Danillon, A. (2009). Gender attribution and gender agreement in French Williams syndrome. Research in Developmental Disabilities, 30, 1523-1540.

Bowers, P., Kirby, J., \& Deacon, H. (2010). The effects of morphological instruction on literacy skills: a systematic review of the literature. Review of Educational Research, 80, 144-179.

Bromberg, H. S., Ullman, M., Marcus, G., Kelly, K., \& Levine, K. (1995). A dissociation of lexical memory and grammar in Williams syndrome: evidence from inflectional morphology. Genetic Counselling, 6, 166-167.

Clahsen, H., \& Almazan, M. (1998). Syntax and morphology in Williams syndrome. Cognition, 68, 167-198. 
Clahsen, H., Ring, M., \& Temple, C. (2004). Lexical and morphological skills in Englishspeaking children with Williams Syndrome. In S. Bartke \& J. Siegmüller (Eds.), Williams Syndrome across languages (pp. 221-244). Amsterdam: John Benjamins.

Demsky, Y, Gass, C., Edwards, W. T., \& Golden, C. J. (1988). Optimal short forms of the Spanish WAIS (EIWA). Assessment, 5, 361-364.

Karmiloff-Smith, A. (1998). Development itself is the key to understanding developmental disorders. Trends in Cognitive Science, 2, 389-398.

Karmiloff-Smith, A. (2008). Research into Williams syndrome: the state of the art. In C. A. Nelson \& M. Luciana (Eds.), Handbook of developmental cognitive neuroscience (pp. 691-700). Cambridge, MA: MIT Press.

Karmiloff-Smith, A., \& Mills, D. L. (2006). Williams Syndrome. In K. Brown (Ed.), Encyclopaedia of language and linguistics, vol. 13 (pp. 585-589). Oxford: Elsevier.

Karmiloff-Smith, A., Grant, J., Berthoud, I., Davies, M., Howlin, P., \& Udwin, O. (1997). Language and Williams syndrome: How intact is 'intact'? Child Development, 68, 274-290.

Karmiloff-Smith, A., Tyler, L. K., Voice, K., Sims, K., Udwin, O., Howlin, P., \& Davies, M. (1998). Linguistic dissociations in Williams syndrome: evaluating receptive syntax in on-line and off-line tasks. Neuropsychologia, 36, 343-351.

Korenberg, J. R., Dai, L., Bellugi, U., Jarvinen-Pasley, A., Mills, D. L., Galaburda, A., Reiss, A. L. \& Pober, B. R. (2008). Deletion of 7q11.23 genes and Williams syndrome. In C. J. Epstein, R. P. Erickson, \& A. Wynshaw-Boris (Eds.), Inborn errors of development: the molecular basis of clinical disorders of morphogenesis (pp. 1544-1552). New York: Oxford University Press.

Krause, M., \& Penke, M., (2002). Inflectional morphology in German Williams syndrome. Brain and Cognition, 48, 410-413.

Lázaro, M., Garayzábal, E., \& Moraleda, E. (2013). Differences on morphological and phonological processing between typically developing children and children with Down syndrome. Research in Developmental Disabilities, 34, 2065-2074.

Levy, Y., \& Bechar, T. (2003). Cognitive, lexical and morpho-syntactic profiles of Israeli children with Williams Syndrome. Cortex, 39, 255-271.

Levy, Y., \& Hermon, S. (2003). Morphological abilities in Hebrew-speaking adolescents. Developmental Neuropsychology, 23, 61-85.

Lukács, Á. (2005). Language abilities in Williams syndrome. Budapest: Akadémiai Kiadó.

Lukács, Á., Racsmány, M., \& Pléh, C. (2001). Vocabulary and morphological patterns in Hungarian children with Williams syndrome: a preliminary report. Acta Linguistica Hungarica, 48, 243-269.

Mervis, C. B., \& Becerra, A. M. (2007). Language and communicative development in Williams syndrome. Mental Retardation and Developmental Disabilities Research Reviews, 13, 3-15.

Paterson, S. J., Brown, J. H., Gsödl, M. K., Johnson, M. H., \& Karmiloff-Smith, A. (1999). Cognitive modularity and genetic disorders. Science, 286, 2355-2357.

Pérez-Pereira, M. (1989). The acquisition of morphemes: some evidence from Spanish. Fournal of Psycholinguistic Research, 18, 289-312.

Pinker, S., \& Prince, A. (1994). Regular and irregular morphology and the psychological status of rules of grammar. In S. D. Lima, R. L. Corrigan, \& G. K. Iverson (Eds.), The reality of linguistic rules (pp. 321-352). Philadelphia, PA: John Benjamins.

Pléh, C., Lukács, A., \& Racsmány, M. (2003). Morphological patterns in Hungarian children with Williams syndrome and the rule debates. Brain and Language, 86, 377-383.

Tassabehji, M. (2003). Williams-Beuren syndrome: a challenge for genotype-phenotype correlations. Human Molecular Genetics, Special, 2, 229-237.

Thomas, M. S. C., Grant, J., Barham, Z., Gsödl, M., Laing, E., Lakusta, L. ... \& KarmiloffSmith, A. (2001). Past tense formation in Williams syndrome. Language and Cognitive Processes, 16, 143-176. 